\title{
AKTIVITAS ANTIOKSIDAN EKSTRAK ETANOL 96\% DAUN SEPAT (Mitragynaspeciosa) DAN DAUN DADANGKAK (Hydrolea spinosa L.)
}

\author{
Rakhmadhan Niah*, Dwi Rizki Febrianti, Novia Ariani \\ Sekolah Tinggi Ilmu Kesehatan (STIKES) ISFI Banjarmasin \\ *: rakhmadhanniah@stikes-isfi.ac.id
}

\begin{abstract}
ABSTRAK
Daun sepat (Mitragynaspeciosa) dan daun dadangkak (Hydrolea spinosa L.) merupakan tumbuhan daerah Kalimantan Selatan. Tumbuhan tersebut memiliki kandungan fenolik dan flavonoid yang tinggi. Kandungan metabolit sekunder tersebut diduga memiliki aktivitas antioksidan. Senyawa fenolik dan flavonoid bekerja melalui mekanisme penangkapan radikal bebas dan mengurangi stress oksidatif. Tujuan penelitian ini adalah mengetahui aktivitas antioksidan daun sepat dan daun dadangkak dengan metode DPPH (1,1-diphenyl-2picrylhydrazyl). Ekstrak daun sepat dan daun dadangkak dibuat dengan metode maserasi menggunakan pelarut etanol 96\%. Ekstrak yang diperoleh diuji aktivitas antioksidan menggunakan metode DPPH (1,1-diphenyl-2picrylhydrazyl). Hasil penelitian menunjukkan aktivitas antioksidan sangat kuat $(<50 \mu \mathrm{g} / \mathrm{mL})$ terdapat pada ekstrak etanol 96\% daun sepat dengan nilai $39.04 \mu \mathrm{g} / \mathrm{mL}$ dan ekstrak etanol $96 \%$ daun dadangkak dengan nilai $41.84 \mu \mathrm{g} / \mathrm{mL}$.
\end{abstract}

Kata kunci: Sepat, Dadangkak, Antioksidan dan DPPH

\section{ABSTRACT}

Sepat leaaf (Mitragynaspeciosa) and dadangkak leaf (Hydrolea spinosa L.) are native plants of South Kalimantan. These plants have high phenolic and flavonoid content. The content of these secondary metabolites is thought to have antioxidant activity. Phenolic compounds and flavonoids work through free radical scavenging mechanisms and reduce oxidative stress. The purpose of this study was to determine the antioxidant activity of sepat leaf and dadangkak leaf using the DPPH $(1,1-$ diphenyl-2picrylhydrazyl) method. Sepat and dadangkak leaf extracts were prepared by maceration method using $96 \%$ ethanol as a solvent. The extract obtained was tested for antioxidant activity using the DPPH (1,1-diphenyl2picrylhydrazyl) method. The results showed that the antioxidant activity was very strong $(<50 \mu \mathrm{g} / \mathrm{mL})$ in the ethanol $96 \%$ extract of sepat leaf with a value of 39.04 $\mu \mathrm{g} / \mathrm{mL}$ and the ethanol extract $96 \%$ of dadangkak leaf with a value of $41.84 \mu \mathrm{g} /$ $m L$.

Keywords: Sepat, Dadangkak, Antioxidants and DPPH

\section{PENDAHULUAN}

Stres oksidatif terdapat diberbagai penyakit, seperti gangguan neurodegeneratif, aterosklerosis, katarak, peradangan, kanker, penyakit jantung koroner dan penyakit Alzheimer. Proses tersebut dihasilkan selama metabolisme sel dan 
Jurnal Insan Farmasi Indonesia, 3(2) Desember 2020 (387-393)

Rakhmadhan Niah

p-ISSN 2621-3184 ; e-ISSN 2621-4032

doi: $10.36387 /$ jifi.v3i2.586

mengarah ke oksidasi beberapa biomolekul, seperti DNA, lipid, dan protein $^{1}$ yang selanjutnya dapat menyebabkan patologis dan proses degeneratif dalam tubuh manusia ${ }^{2}$.

Antioksidan, khususnya antioksidan alami, banyak diteliti dikarenakan kemampuannya untuk menjaga keseimbangan oksidasiantioksidan ${ }^{1}$. Mekanisme antioksidan alami adalah engan mengganggu propagasi reaksi berantai pengoksidasi atau dengan menghambat pembentukan radikal ${ }^{2}$. Tanaman dengan kandungan fenolik dan flavonoid yang tinggi memiliki aktivitas antioksidan yang tinggi ${ }^{3}$.

Daun

(Mitragynaspeciosa) dan daun dadangkak (Hydrolea spinosa L.) merupakan tumbuhan yang banyak tumbuh di Kalimantan Selatan. Secara emperis daun sepat dan daun dadangkak digunakan sebagai minuman seduhan yang diduga kaya akan antioksidan. Mekanisme antioksidan tanaman tersebut diduga berasal pada senyawa flavonoid ${ }^{3}$.

Flavonoid merupakan senyawa yang memiliki sejumlah gugus hidroksil yang tidak tersubstitusi ${ }^{4}$.
Pembuktian bahwa daun sepat dan daun dadangkak memiliki kemampuan antioksidan perlu dikaji menggunakan metode DPPH. Semakin tinggi kadar flavonoid total maka semakin tinggi aktivitas antioksidan tumbuhan tersebut ${ }^{5}$.

Pengujian aktivitas antioksidan dilakukan, meliputi aktivitas antioksidan seluler menggunakan 2,2difenil-1-picrylhydrazyl (DPPH). Uji aktivitas antioksidan seluler memberikan pemahaman yang komprehensif tentang aktivitas antioksidan $^{6}$. Hasil penelitian ini akan sangat membantu untuk memahami manfaat kesehatan dari daun sepat dan dadangkak sebagai antioksidan.

\section{METODE PENELITIAN}

\section{Alat}

Alat yang digunakan pada penelitian ini adalah spektrofotometri UV-Visible $\left(\right.$ Shimadzu $\left.^{\circledR}\right)$ type 1700 , timbangan digital (Ohauss $\left.{ }^{\circledR}\right)$, rotary evaporator (Heidolph), labu takar (Pyrex $\left.{ }^{\circledR}\right)$, Becker glass (Pyrex $\left.{ }^{\circledR}\right)$, mikropipet, pipet tetes, alumunium foil.

\section{Bahan}

Bahan yang digunakan dalam penelitian ini adalah sampel daun 
Jurnal Insan Farmasi Indonesia, 3(2) Desember 2020 (387-393)

Rakhmadhan Niah

p-ISSN 2621-3184; e-ISSN 2621-4032

doi: $10.36387 /$ jifi.v3i2.586

sepat (Mitragynaspeciosa), daun

Serbuk daun kemudian diekstraksi

dadangkak (Hydrolea spinosa L.),

dengan menggunakan metode

$\mathrm{DPPH}$

(2,2-diphenyl-1-

maserasi dengan pelarut etanol 96\%.

picrylhydrazyl) (pa.merck), etanol

96\% (teknis).

Ekstrak kental yang diperoleh dihitung persentase rendemennya ${ }^{7}$.

\section{Jalannya penalitian}

\section{Determinasi Tanaman}

4. Pengujian

Aktivitas

\section{Sampel}

tanaman sepat diambil didaerah

Barabai dan tanaman dadangkak

diambil didaerah Banjarmasin,

Kalimantan Selatan. Determinasi

dilakukan di Laboratorium Fakultas

Matematika dan Ilmu Pengetahuan

Alam, Universitas Lambung

Mangkurat.

2. Pengambilan dan

Pengolahan Sampel

Sampel daun

sepat dan dadangkak dibersihkan dari kotoran-kotoran yang menempel dengan cara mencucinya dengan air mengalir. Tahap berikutnya dilakukan perajangan terhadap daun, pengeringan menggunakan sinar matahari langsung, Sortasi kering dan dihaluskan menjadi serbuk ${ }^{3}$.

3. Pembuatan Ekstrak Etanol 96\% Daun Sepat dan Daun Dadangkak

Antioksidan Menggunakan Metode DPPH

DPPH (1,1-diphenyl-

2picrylhydrazyl) dibuat larutan stok 80 ppm. Buat konsentrasi sampel uji 10 ppm, 20 ppm, 30 ppm, 40 ppm dan 50 ppm. Masing-masing sampel uji diambil $2 \mathrm{~mL}$ dan dimasukkan kedalam tabung reaksi. Tambahkan larutan DPPH sebanyak $2 \mathrm{~mL}$, kemudian dikocok dan diinkubasi selama \pm 15 menit. Hitung serapan menggunakan spektrometer UVVIS dengan panjang gelombang $517 \mathrm{~nm}$, sehingga didapat nilai $\mathrm{IC}_{50}{ }^{8,9}$.

\section{Analisis Data}

Aktivitas penangkapan radikal bebas dihitung sebagai presentase berkurangnya warna DPPH dengan menggunakan persamaan: 
Jurnal Insan Farmasi Indonesia, 3(2) Desember 2020 (387-393)

Rakhmadhan Niah

p-ISSN 2621-3184 ; e-ISSN 2621-4032

doi: 10.36387/jifi.v3i2.586

$\%$ Hambat $=($ Absorbansi blankoAbsorbansi sampel/Absorbansi blanko) x $100 \%$

Nilai $\mathrm{IC}_{50}$ dihitung dengan menggunakan dengan menggunakan persamaan regresi persentase inhibisi ${ }^{9}$. Nilai $\mathrm{IC}_{50}$ menyatakan besarnya konsentrasi larutan sampel yang dapat meredam radikal bebas DPPH sebesar 50\%. Dari persamaan $\mathrm{y}=\mathrm{bx}+\mathrm{a}$ dapat dihitung nilai dengan menggunakan rumus ${ }^{9}$.

\section{PEMBAHASAN}

Determinasi tumbuhan dilakukan di Labolatorium FMIPA Universitas Lambung Mangkurat, hasil determinasi dari daun sepat menunjukan species

Mitragynaspeciosa . Hasil determinasi daun dadangkak menunjukkan spesies Hydrolea spinosa L. Pada proses ekstraksi diperoleh ekstrak dengan nilai rendemen ekstrak etanol 96\% daun sepat sebesar 23,13\% dan ekstrak etanol 96\% daun dadangkak $29,80 \%$. Rendemen yang diperoleh lebih banyak dari rendemen penelitian sebelumnya $^{3}$ dan penelitian sebelumnya menggunakan metanol. Hal tersebut menunjukkan daun sepat

dan daun dadangkak diduga banyak memiliki senyawa metabolit sekunder semi polar mengarah ke nonpolar, seperti fenol, flavonoid, alkaloid dan Tannin.

Tanaman yang memiliki fenolik dan flavonoid dapat bersifat sebagai antioksidan. Fenol adalah senyawa yang memiliki setidaknya satu gugus hidroksil dan keberadaan gugus hidroksil ini menyebabkan semua senyawa fenolik menjadi reduktan. Reduksi berarti transfer elektron, di mana elektron ini disediakan oleh fenol sebagai atom hidrogen dengan elektron tunggal $(\mathrm{H} \bullet)$. Atom ini dihasilkan dari pemecahan ikatan $\mathrm{O}-$ $\mathrm{H}$ dengan proses di mana masingmasing fragmen mempertahankan salah satu elektron. $\mathrm{H} \bullet$ ini akan mengurangi jumlah oksidasi yang disebabkan oleh radikal bebas ${ }^{10,11}$. Flavonoid dapat berkontribusi karena adanya ikatan rangkap terkonjugasi, gugus hidroksil pada $\mathrm{C}^{\prime}$ ' dan $\mathrm{C}^{\prime}$, dan katekol dalam cincin B dalam struktur flavonoid. Struktur semacam itu menjadikan flavonoid sebagai sasaran untuk diserang oleh radikal bebas dengan cara menggerakkan awan elektron di sekitar cincin aromatik 
Jurnal Insan Farmasi Indonesia, 3(2) Desember 2020 (387-393)

Rakhmadhan Niah

p-ISSN 2621-3184 ; e-ISSN 2621-4032

doi: 10.36387/jifi.v3i2.586

dan donor elektron, sehingga

menghambat reaksi berantai dan

menstabilkan bentuk radikal ${ }^{12}$. Namun

untuk mengkaji hal tersebut perlu

dilakukan pengujian aktivitas

antioksidan menggunakan metode

DPPH. Pengujian aktivitas

antioksidan dengan metode DPPH

memberikan nilai $\mathrm{IC}_{50}$ yang berbeda

antara kedua tumbuhan yang dapat

dilihat pada gambar 1. Efektivitas

suatu sampel untuk menangkal

radikal bebas dari metode DPPH

dinamakan dengan $\mathrm{IC}_{50}$, yaitu

konsentrasi yang dapat meredam 50\%

semakin kecil maka semakin besar aktivits antioksidannya ${ }^{10}$. Aktivitas antioksidan sangat kuat $(<50 \mu \mathrm{g} / \mathrm{mL})$ terdapat pada ekstrak etanol 96\% daun sepat dan ekstrak etanol 96\% daun dadangkak dengan nilai berturut-turut $39.04 \mu \mathrm{g} / \mathrm{mL} ; 41.84$ $\mu \mathrm{g} / \mathrm{mL}$. Aktivitas antioksidan tersebut termasuk aktivitas antioksidan sangat kuat karena nilai $\mathrm{IC}_{50}$ kurang dari 50 $\mu \mathrm{g} / \mathrm{mL}^{10}$. Hasil tersebut dapat disimpulkan pelarut etanol $96 \%$ sesuai untuk mengekstraksi metabolit-metabolit sekunder yang memiliki aktivitas antioksidan. radikal bebas DPPH. Nilai $\mathrm{IC}_{50}$

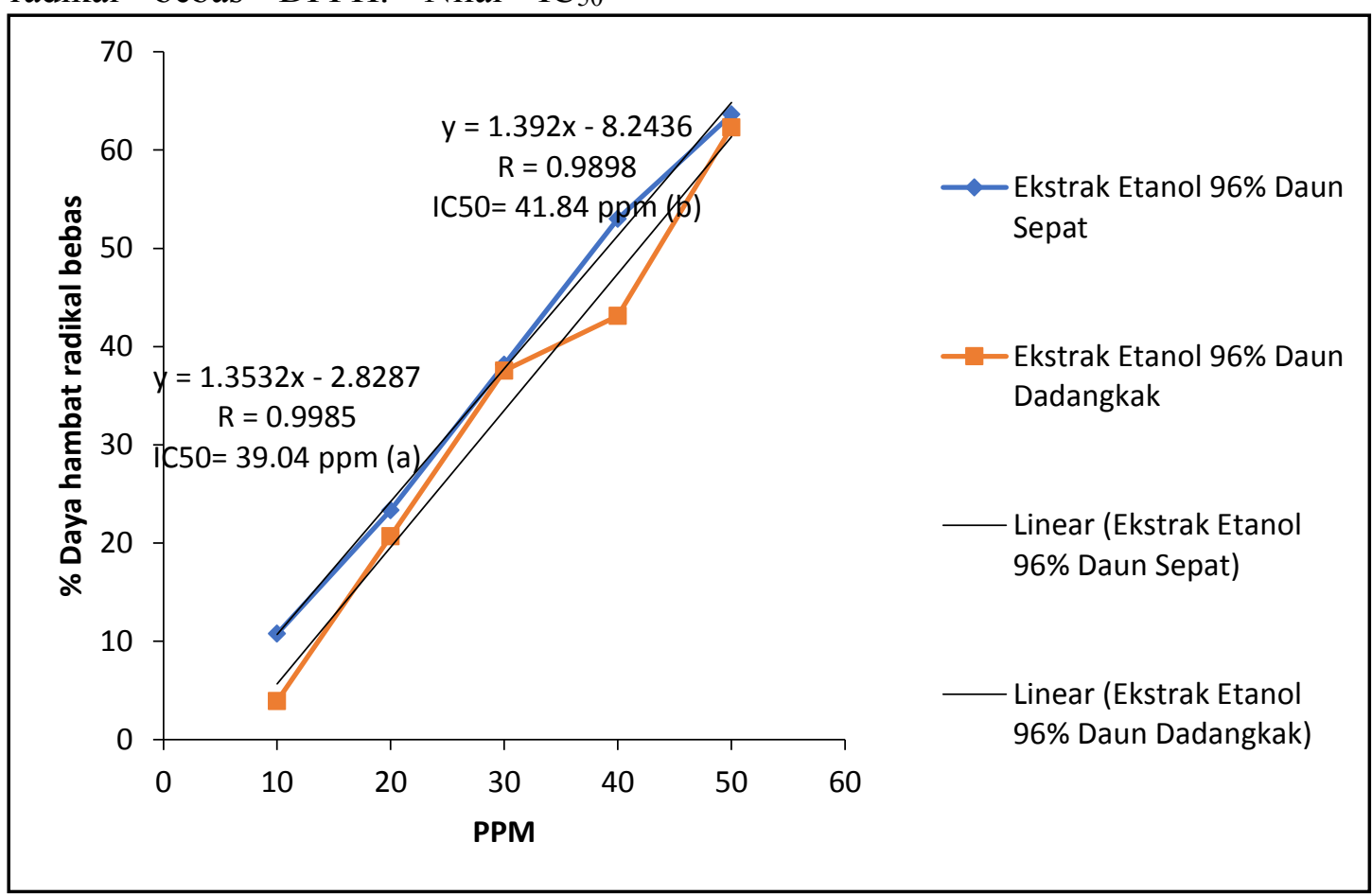

Gambar 1. Regresi Linier Aktivitas Antioksidan (IC 50) Ekstrak Etanol 96\% daun sepat (a) dan daun dadangkak (b) 
Jurnal Insan Farmasi Indonesia, 3(2) Desember 2020 (387-393)

Rakhmadhan Niah

p-ISSN 2621-3184 ; e-ISSN 2621-4032

doi: 10.36387/jifi.v3i2.586

\section{KESIMPULAN}

Aktivitas antioksidan sangat kuat $(<50 \mu \mathrm{g} / \mathrm{mL})$ terdapat pada kedua ekstrak, yaitu pada ekstrak etanol 96\% daun sepat dan ekstrak etanol $96 \%$ daun dadangkak dengan nilai berturut-turut $39.04 \mu \mathrm{g} / \mathrm{mL}$; $41.84 \mu \mathrm{g} / \mathrm{mL}$

\section{UCAPAN TERIMAKASIH}

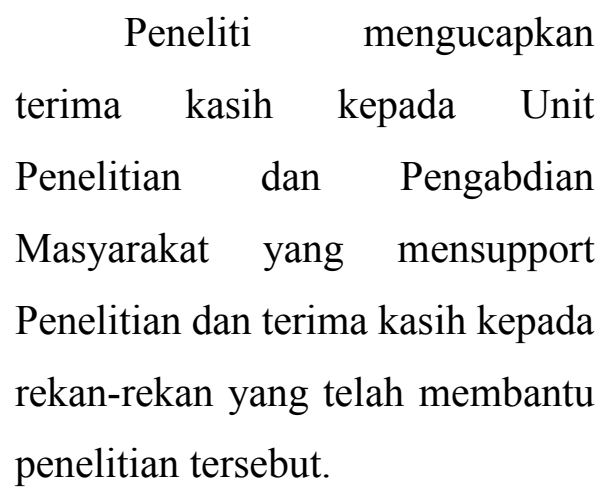

\section{DAFTAR PUSTAKA}

1. Fredotović, Ž., Šprung, M., Soldo, B., Ljubenkov, I., Budić-Leto, I., Bilušić, T., Čikeš-Čulić, V., Puizina, J., 2017. Chemical composition and biological activity of allium cepa $\mathrm{L}$. and allium $\times$ cornutum (Clementi ex Visiani 1842) methanolic extracts. Molecules 22, 448.

2. Tu, J., Shi, D., Wen, L., Jiang, Y., Zhao, Y., Yang, J., ... \& Yang, B. 2019. Identification of moracin $\mathrm{N}$ in mulberry leaf and evaluation of antioxidant activity. Food and Chemical Toxicology, 132, 110730.

3. Niah, R., \& Kumalasari, E. 2019. Profil Senyawa Dan Aktivitas Antioksidan Ekstrak
Daun

Sepat

(Mitragynaspeciosa) Dan Daun Dadangkak (Hydrolea spinosa L.). Jurnal Ilmiah Ibnu Sina, 4(2), 391-399.

4. Adhayanti, I., Abdullah, T., \& Romantika, R. 2018. Uji Kandungan Total Polifenol Dan Flavonoid Ekstrak Etil Asetat Kulit Pisang Raja (Musa Paradisiaca Var. Sapientum), Media Farmasi, 14(1), 39-45.

5. Indayani, M. K., Asnani, A., \& Suwarjoyowirayatno, S. 2019. Pengaruh Metode Pengeringan Yang Berbeda Terhadap Komposisi Kimia, Vitamin C Dan Aktivitas Antioksidan Anggur Laut Caulerpa Racemosa. Jurnal Fish Protech, 2(1).

6. Wen, L., Zhao, Y., Jiang, Y., Yu, L., Zeng, X., Yang, J., ... \& Yang, B. 2017. Identification of a flavonoid C-glycoside as potent antioxidant. Free Radical Biology and Medicine, 110, 92-101.

7. Niah, R., \& Febrianti, D. R. 2018. Optimasi Ekstrak Daun Karamunting (Melastoma malabathricum L.) dari Berbagai Pelarut sebagai Antibakteri Tifoid, Jurnal Insan Farmasi Indonesia, 1(2), 191-200.

8. Lestari, D. M., Mahmudati, N., Sukarsono, S., Nurwidodo, N., \& Husamah, H. 2018. Aktivitas Antioksidan Ekstrak Fenol Daun Gayam (Inocarpus Fagiferus Fosb). Majalah Ilmiah Biologi Biosfera: A Scientific Journal, 35(1), 3743. 
Jurnal Insan Farmasi Indonesia, 3(2) Desember 2020 (387-393)

Rakhmadhan Niah

p-ISSN 2621-3184 ; e-ISSN 2621-4032

doi: 10.36387/jifi.v3i2.586

9. Safitri, F. W., Syahreza, A., \& Sulistyaningrum, I. H. 2016. Antioxidant Activities And Antioxidant Cream Formulation Of Corn Silk (Zea Mays L) Extract, Sains Medika: Jurnal Kedokteran Dan Kesehatan, 7(2), 64-69.

10. Molyneux, P. The use of the stable free radical diphenylpicrylhydrazyl

(DPPH) for estimating antioxidant activity. Songklanakarin J. sci. technol, 2004;26(2), 211-219.

11. Guaratini, T., Lopes, N. P., Marinho-Soriano, E., Colepicolo, P., \& Pinto, E.. Antioxidant activity and

chemical composition of the non polar fraction of Gracilaria domingensis (Kützing) Sonder ex Dickie and Gracilaria birdiae (Plastino \& Oliveira). Revista Brasileira de Farmacognosia, 2012; 22(4), 724-729.

12. Nuri, N., Puspitasari, E., Hidayat, M. A., Ningsih, I. Y., Triatmoko, B., \& Dianasari, D. (2020). Pengaruh Metode Ekstraksi terhadap Kadar Fenol dan Flavonoid Total, Aktivitas Antioksidan serta Antilipase Daun Jati Belanda (Guazuma ulmifolia). Jurnal Sains Farmasi \& Klinis, 7(2), 143150. 